\title{
Pathology and morphometry of Hystrichis acanthocephalicus (Nematoda) from Phimosus infuscatus (Pelecaniformes) in southern Brazil
}

\author{
Patologia e morfometria de Hystrichis acanthocephalicus (Nematoda) em \\ Phimosus infuscatus (Pelecaniformes) no Sul do Brasil
}

Simone Scheer ${ }^{1 *}$; Márcia Raquel Pegoraro Macedo ${ }^{1}$; Mauro Pereira Soares ${ }^{2}$; Camila Costa Schramm ${ }^{1}$; Gertrud Muller ${ }^{1}$

\begin{abstract}
${ }^{1}$ Laboratório de Parasitologia de Animais Silvestres - LAPASIL, Departamento de Microbiologia e Parasitologia, Instituto de Biologia, Universidade Federal de Pelotas - UFPel, Campus Universitário Capão do Leão, Pelotas, RS, Brasil

${ }^{2}$ Departamento de Patologia Animal e Veterinária Preventiva, Universidade Federal de Pelotas - UFPel, Campus Universitário Capão do Leão, Pelotas, RS, Brasil
\end{abstract}

Received September 22, 2016

Accepted October 31, 2016

\begin{abstract}
Species of Hystrichis are parasite nematodes of the digestive tract of aquatic birds in South America, Europe and Asia. In Brazil, Hystrichis acanthocephalicus has been reported in Phimosus infuscatus. There are few data on the morphometry of this species and there are no reports on pathological conditions that it causes. Therefore, the purpose of this study was to report morphometric data from $H$. acanthocephalicus and describe the pathological effects of this parasite on the Phimosus infuscatus proventriculus. Thirty gastrointestinal tracts of P. infuscatus were examined to search for nematodes and $H$. acanthocephalicus occurred in $83 \%$ of hosts. Were measured the total length and body width of males and females, and of their respective cuticular spines, esophagus, spicules and eggs, and the internal and external diameter of copulatory bursa. Histopathological examination revealed parasitic structures in the proventriculus from the lumen (anterior end) to the outer layers of the organ (intermediate and posterior parts), in which we observed inflammatory reaction with infiltration of heterophils, hemorrhage and hemosiderin. The results of this study of histopathology, morphometry and parasitological indices are the first ones reported to $H$. acanthocephalicus and should contribute to the identification and recognition in cases of outbreaks in the Neotropical region.
\end{abstract}

Keywords: Aquatic bird, helminths, pathology, morphometry.

\section{Resumo}

Espécie de Hystrichis são nematoides parasitos do trato digestório de aves aquáticas, na América do Sul, Europa e Ásia. No Brasil, foi registrado Hystrichis acanthocephalicus, em Phimosus infuscatus. Existem poucos dados sobre a morfometria e não há registros relativos à patologia desta espécie. Portanto, o objetivo deste estudo foi relatar dados morfométricos de $H$. acanthocephalicus e descrever os efeitos patológicos deste parasito no proventrículo de Phimosus infuscatus. Foram examinados trinta tratos gastrintestinais de $P$. infuscatus para a pesquisa de nematoides e $H$. acanthocephalicus ocorreu em $83 \%$ dos hospedeiros. Mediu-se o comprimento total e largura do corpo de machos e fêmeas, dos espinhos cuticulares, do esôfago, dos espículos, dos ovos, respectivamente, e a largura interna e externa da bolsa copuladora. Nos exames histopatológicos foram encontradas estruturas parasitárias no proventrículo, desde o lúmen (porção anterior) até as camadas mais externas do órgão (porçôes intermediária e posterior), nas quais se observou reaçẫo inflamatória com infiltrado de heterófilos, presença de hemorragia e deposição de hemossiderina. Os resultados desse estudo sobre histopatologia, morfometria e índices parasitológicos são os primeiros relatados para $H$. acanthocephalicus e deverão contribuir para a identificação e reconhecimento em casos de surtos na região Neotropical.

Palavras-chave: Ave aquática, helmintos, patologia, morfometria.

\footnotetext{
*Corresponding author: Simone Scheer. Departamento de Microbiologia e Parasitologia, Instituto de Biologia, Universidade Federal de Pelotas - UFPel, Campus Universitário Capão do Leão, CP 354, CEP 96010-900, Pelotas, RS, Brasil. e-mail: sissi_sls@hotmail.com
} 


\section{Introduction}

Dioctophymatidae are composed of nematode species belonging to three genera that parasitize vertebrates: Eustrongylides Jägerskiöld, 1909 and Hystrichis Molin, 1861, which are parasites of the esophagus, proventriculus and/or gizzard of aquatic birds; and Dioctophyma Goeze, 1782, which are parasites of the kidneys of wild and domestic carnivores. All the species include oligochaetes as intermediate hosts (ANDERSON, 2000).

Hendricks et al. (1969) established five species of Hystrichis: Hystrichis coronatus Molin, 1861 in the gizzard of Mergus merganser Linnaeus, 1758 (Anseriformes: Anatidae); Hystrichis pachicephalus Molin, 1861 in the gizzard of Cygnus olor Gmelin, 1789 (Anseriformes: Anatidae); Hystrichis corvi Hendricks, 1969, in the proventricular glands of Corvus brachyrhynchos Brehm, 1822 (Passeriformes: Corvidae); Hystrichis tricolor Dujardin, 1845 in the esophagus of Anas tadorna Linnaeus, 1758 (Anseriformes: Anatidae); and Hystrichis acanthocephalicus Molin, 1861 in the proventricular glands of Phimosus infuscatus Lichtenstein, 1823 (Pelecaniformes: Threskiornithidae), host that is object of this study.

Phimosus infuscatus known as the bare-faced ibis, inhabits shallow-water regions - flooded fields, wetlands and rice fields - where it finds the main items of its diet: aquatic arthropods, crustaceans, mollusks, seeds and leaves (BELTON, 2003). These birds are widely distributed throughout South America and can be observed in all seasons of the year (SICK, 1997).

The helminths reported in P. infuscatus in the Neotropical region include the cestode Chimaerula bonai Georgiev, 2000 (GEORGIEV \& VAUCHER, 2000), the nematodes Eustrongylides sp. and H. acanthocephalicus and the trematode Stomylotrema sp. (TRAVASSOS \& FREITAS, 1942). The objective of the present study was to describe the histopathological alterations to the proventriculus of Phimosus infuscatus caused by Hystrichis acanthocephalicus and to report new morphometric data on this parasite.

\section{Materials and Methods}

The birds examined were collected in the municipalities of Pelotas ( $31^{\circ} 46^{\prime} 19^{\prime}$ 'S; 520 20'33” W), Capão do Leão ( $31^{\circ} 46^{\prime} 3$ ' S; $52^{\circ} 26^{\prime} 55^{\prime \prime} \mathrm{W}$ ) and Rio Grande (31 ${ }^{\circ} 51^{\prime} 12.1^{\prime \prime} \mathrm{S}$; $52^{\circ} 18$ ' 48.0” W), in Rio Grande do Sul State, Brazil. We examined thirty specimens of $P$. infuscatus (16 males and 14 females), nine of which were donated by the Núcleo de Reabilitação da Fauna Silvestre e Centro de Triagem de Animais Silvestres da Universidade Federal de Pelotas (NURFS-CETAS/UFPel), where they had died. The others were shot using hunting guns between December 2015 and February 2016, with authorization from the Instituto Chico Mendes de Conservação da Biodiversidade - Sistema de Autorização e Informação em Biodiversidade/ICMBIO-SISBIO no. 507541); and from the CEEA/UFPel ethics committee for animal use, under no. 21300013.

The necropsies on the birds and helminth collection and preparation followed the recommendations of Amato \& Amato (2010)
The proventriculus of each bird was subjected to enzymatic digestion in order to collect parasites. This was done in a solution of $1 \%$ hydrochloric acid and $10 \%$ pepsin at $37^{\circ} \mathrm{C}$ for 45 minutes. After collection of parasites, the specimens were fixed in AFA (solution of ethanol, formaldehyde and acetic acid) and stored in alcohol 70\%. The nematodes were clarified using Amman's lactophenol and were observed under an Olympus CX21 microscope in order to identify them and obtain morphometric data. They were then identified morphologically (HENDRICKS et al., 1969). The ecological terms following the recommendations of Bush et al. (1997).Voucher specimens (male and female) were deposited in the Coleção de Helmintos do Laboratório de Parasitologia de Animais Silvestres do Instituto de Biologia, Universidade Federal de Pelotas (CHLAPASIL/UFPel), under the number 636.

For histopathological analysis, two proventriculus were fixed in $10 \%$ buffered formalin. Each proventriculus was processed in accordance with the recommendations of Caputo et al. (2009).

\section{Results}

Hystrichis acanthocephalicus was found in the proventriculus of 25 birds. A total of 90 specimens ( 58 females and 32 males) of $H$. acanthocephalicus was collected, with prevalence of $83 \%$, average abundance of 3.0 and mean intensity of infection of 3.6 nematodes per host.

The morphometric description was based on five male specimens and five female specimens (adults) and 25 eggs. The females were slightly longer than the males (Table 1), with mean lengths of $37.9 \mathrm{~mm}$ and $32.5 \mathrm{~mm}$, respectively. The spines are of uniform size at different points in the anterior end (Figure 1a). The eggs presented morphology specific to the species (Figure 1d and Figure 1e), with a symmetrical format covered by a thick, rough shell marked by a irregularly shaped ridges; morphologically characteristic of Dioctophymatidae. A single spicule was seen in each male. The copulatory bursa also showed uniform measurements among the different specimens (Figure 1b).

In the histological analysis, we observed parasite structures in the proventriculus of $P$. infuscatus. Parasites were found with the anterior end inserted in the mucous glands, directed towards the lumen of the proventriculus. The intermediate and posterior regions were spread along the submucosa, muscle and adventitia layers (Figure 2a). The regions of parasite structures showed infiltration of heterophils, hemorrhage and hemosiderin (Figure 2b). The intermediate and posterior regions were mainly in the muscle and adventitia layers. In these regions, adult females with a pregnant uterus (Figure 2f) and calcified parasites (Figure 2c and Figure $2 \mathrm{~d}$ ) were found. The parasites were delimited by a conspicuous hypereosinophilic halo (cellular remains), a thick layer of multinucleated giant cells and a fibrous connective tissue capsule (Figure 2e). In addition, bordering these regions, a conspicuous inflammatory response with the presence of mononuclear cells and heterophils and hemosiderin (Figure $2 \mathrm{~b}$ and Figure $2 \mathrm{~d}$ ) was observed. Some areas had necrotic crypts with cellular remains in the lumen and inflammatory responses of different degrees of severity (Figure $2 \mathrm{~g}$ ). 
Table 1. Measurements on adults and eggs of Hystrichis acanthocephalicus collected from of Phimosus infuscatus ( $\mathrm{n}=30$ ), from Rio Grande, Pelotas and Capão do Leão municipalities, in Rio Grande do Sul State. All measurements are in micrometers, except for the length and width of the body, which are in millimeters.

\begin{tabular}{|c|c|c|c|c|c|c|}
\hline \multirow{2}{*}{ Feature } & \multicolumn{3}{|c|}{ Females $(n=5)$} & \multicolumn{3}{|c|}{ Males $(n=5)$} \\
\hline & & $\bar{x}$ & SD & & $\bar{x}$ & SD \\
\hline \multicolumn{7}{|l|}{ Body } \\
\hline Overall length & $32.9-42.9$ & 37.9 & \pm 3.958 & $25.9-33.4$ & 32.5 & \pm 3.44 \\
\hline Maximum width & $1.5-1.8$ & 1.646 & \pm 0.134 & $1.5-1.8$ & 1.720 & \pm 0.117 \\
\hline \multicolumn{7}{|l|}{ Esophagus } \\
\hline Overall length & $7.3-7.85$ & 7.516 & \pm 0.204 & $5.07-6.75$ & 6.250 & \pm 0.673 \\
\hline Maximum width & $0.22-0.28$ & 0.258 & \pm 0.029 & $0.18-0.25$ & 0.212 & \pm 0.029 \\
\hline \multicolumn{7}{|l|}{ Spicules } \\
\hline Length & & & & $3.18-3.40$ & 3.3 & \pm 0.09 \\
\hline Width & & & & $0.04-0.05$ & 0.048 & \pm 0.004 \\
\hline \multicolumn{7}{|l|}{ Copulatory bursa } \\
\hline Complete diameter & & & & $0.233-0.278$ & 0.253 & \pm 0.016 \\
\hline Internal diameter & & & & $0.105-0.173$ & 0.136 & \pm 0.024 \\
\hline \multicolumn{7}{|l|}{ Spines $(n=50)$} \\
\hline Length & $0.023-0.035$ & 0.029 & \pm 0.003 & $0.02-0.033$ & 0.027 & \pm 0.004 \\
\hline Width & $0.01-0.033$ & 0.012 & \pm 0.004 & $0.01-0.03$ & 0.013 & \pm 0.004 \\
\hline \multicolumn{7}{|l|}{ Eggs $(n=25)$} \\
\hline Length & 0.07-0.09 & 0.078 & \pm 0.006 & & & \\
\hline Width & $0.04-0.06$ & 0.0432 & \pm 0.005 & & & \\
\hline
\end{tabular}

$\mathrm{SD}=$ Standard deviation

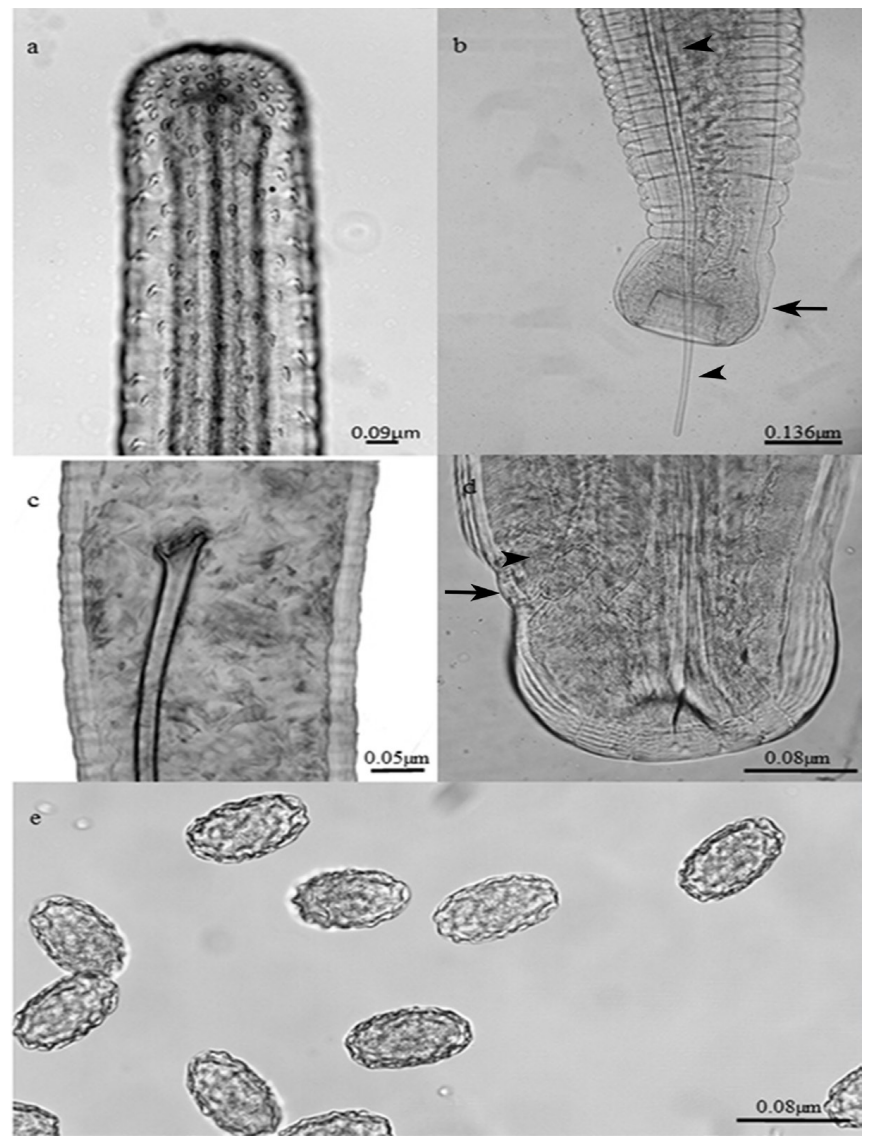

Figure 1. (a) Anterior end; (b) Posterior end of male showing the copulatory bursa (arrow) and the spicule (arrow tip); (c) Proximal end of spicule; (d) Posterior end of female showing the egg (arrow tip) in the vulvar opening (arrow); (e) Eggs.

\section{Discussion}

In Brazil, there is only one record of $H$. acanthocephalicus in the proventricular glands of P. infuscatus (VICENTE et al., 1995), but neither the number of birds examined nor the geographical location were reported. In the present study, the hosts were caught systematically and central geographical coordinates relative to the sampling points were supplied, including for the hosts that were donated by NURFS.

In the morphological description of $H$. acanthocephalicus in P. infuscatus, only the length and width measurements of the males and females were reported: $2 \mathrm{~mm}$ and $35 \mathrm{~mm}$, and $35 \mathrm{~mm}$ and $3 \mathrm{~mm}$ (MOLIN, 1861), respectively. In the present study, we found differences in length and width, both among the males and among the females, thus agreeing with what was described by Molin (1861). The males were shorter and wider than the females (32.5 $\mathrm{mm}$ in length and $1.720 \mathrm{~mm}$ in width). The females, in turn, were slightly longer and narrower $(37.9 \mathrm{~mm}$ in length and $1.646 \mathrm{~mm}$ in width) than those originally described, and in relation to the males. The esophagus and cuticular spines of the females were also of different sizes, compared with those of the males. Measurements for the copulatory bursa and spicules of P. infuscatus were reported here for the first time. Hence, it was only possible to make morphometric comparisons with other species of Hystrichis.

Hystrichis acanthocephalicus is smaller than $H$. corvi: the females measure $90.70 \mathrm{~mm} \times 2.11 \mathrm{~mm}$ and the males, $40.79 \mathrm{~mm}$ x $0.98 \mathrm{~mm}$. However, the copulatory bursa of $H$. corvi is smaller, with a diameter of $138 \mu \mathrm{m}$ (HENDRICKS et al., 1969), compared with $253 \mu \mathrm{m}$ for $H$. acanthocephalicus (Figure $1 \mathrm{~b}$ and Figure 1c). Reports of the female length and width are available for $H$. tricolor and 


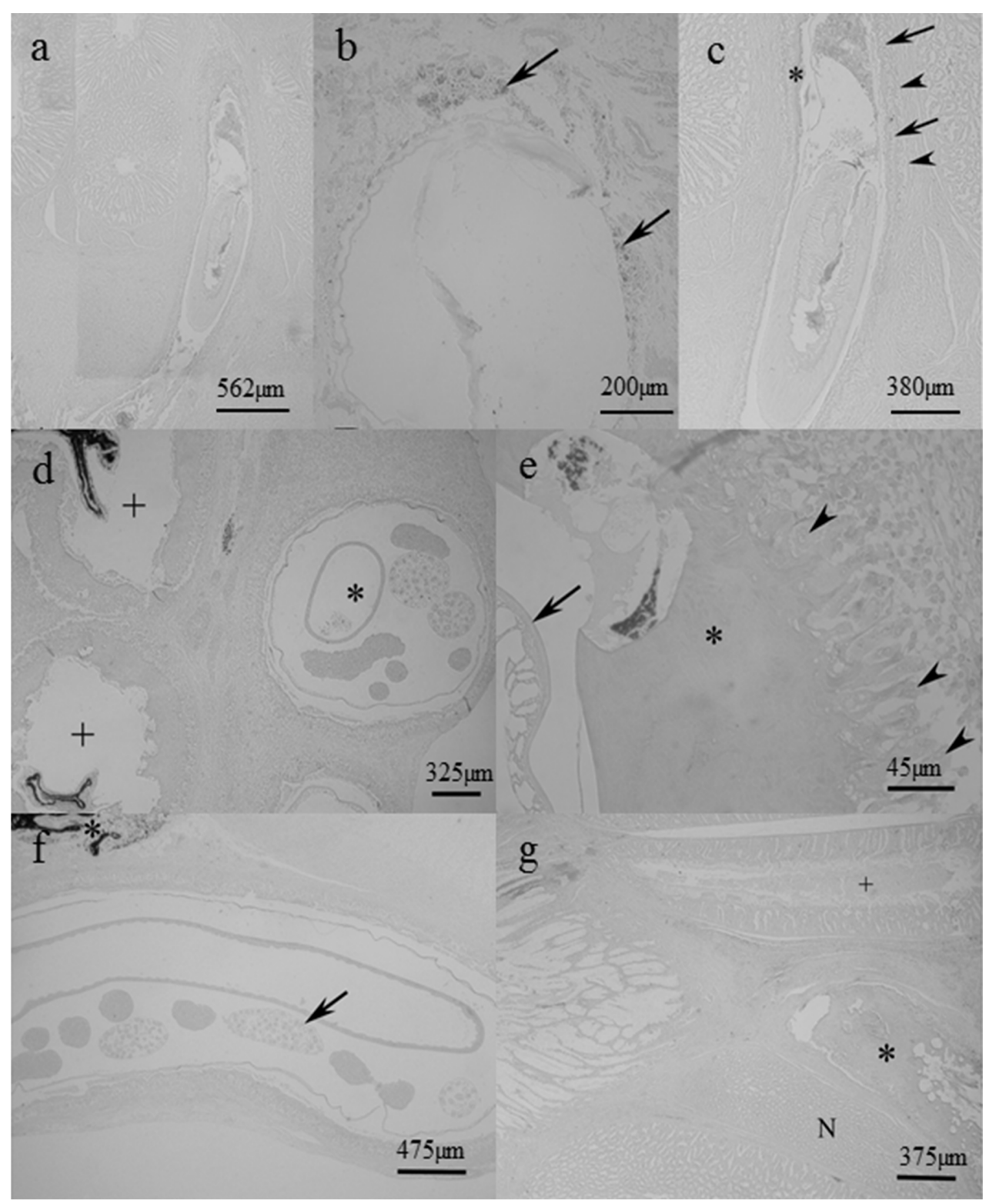

Figure 2. (a) Parasite encapsulated in the proventriculus, extending from the mucosa to the adventitia; (b) Hemosiderin around the anterior end (arrow); (c) Parasite bounded by necrosis $\left(^{*}\right)$, inflammatory multinucleated cells (arrow) and fibrosis (arrow tip); (d) Viable parasite $\left(^{*}\right)$ bounded by hypereosinophilic halo, surrounded by infiltrated inflammatory of multinucleated giant cells, fibrosis and abundant inflammatory infiltrate of mononucleosis; necrotic parasite (+); (e) External cuticle of the parasite (arrow); necrotic tissue surrounding the parasite $\left(^{*}\right)$ and multinucleated giant-cell layer (arrow tip); (f) Adult parasite in adventitia layer; gravid uterus with eggs (arrow); remains of parasite undergoing degradation process and necrosis $\left(^{*}\right)$; $(\mathbf{g})$ Normal crypt $(\mathrm{N})$; parasite inside crypt $\left(^{*}\right)$; crypt undergoing degeneration process with remains of cells in the lumen $(+)$.

H. coronatus: $35 \mathrm{~mm} \times 5 \mathrm{~mm}$, and $27 \mathrm{~mm} \times 3 \mathrm{~mm}$, respectively. For $H$. pachicephalus, only the length of the female is known: $30 \mathrm{~mm}$ (MOLIN, 1861). Thus, there is a small difference in relation to the measurements of $H$. acanthocephalicus.

Hystrichis acanthocephalicus and $H$. tricolor can be differentiated through the morphology of the eggs (HENDRICKS et al., 1969). Hystrichis acanthocephalicus has a shell marked by a network of irregularly shaped ridges and the eggs measure $0.078 \mu \mathrm{m}$ in length x $0.0432 \mu \mathrm{m}$ in width. Hystrichis tricolor has eggs of regular shape, measuring $85 \mu \mathrm{m}$ by $50 \mu \mathrm{m}$ (AL-LABBAN et al., 2013). The irregular shape of $H$. acanthocephalicus eggs, along with the disposition of cuticular spines, was essential for species identification in the present study. The morphometric data generated were important for species differentiation.

Hystrichis spp. have been reported in many hosts and geographical regions with varied prevalence, mean abundance and intensity: Hystrichis tricolor was reported in Anas platyrhynchos, in Poland (KAVETSKA et al., 2012) with $\mathrm{P}=0.19 \%$; and larvae of $H$. tricolor were reported in Bufo viridis, in Uzbekistan (VASHETKO \& SIDDIKOV, 1999), with $\mathrm{A}=0.004$ and $\mathrm{MI}=0.4$, and. B. viridis is probably a paratenic host. Al-Labban et al. (2013) reported $H$. tricolor with $\mathrm{P}=10 \%$, in ducks (Anatidae), in Iraq. 
Youssefi et al. (2010) provided the first report of Hystrichis sp. in the digestive tract of otters (Lutra lutra), in Iran. In a comparative study between Gallinula chloropus cachinnans and Porphyrula martinica (Rallidae), in Florida, Kinsella et al. (1973) found $H$. tricolor with prevalence of $10 \%$ for Gallinula chloropus cachinnans and 2\% for Porphyrula martinica (Rallidae), in the proventriculus of both birds. Canaris et al. (2010), in Mexico, reported $H$. tricolor with $\mathrm{P}=58 \%$ and $\mathrm{A}=5.08$ in Limnodromus scolopaceus (Scolopacidae). The results from these studies, except Canaris et al. (2010), show distinctly lower rates than those in P. infuscatus $(\mathrm{P}=83 \%)$. We attribute this difference in prevalence to the climatic conditions of the places where the studies were conducted. The higher prevalence in Mexico and Brazil, which are both in the Neotropical region, probably occurred because of better environmental conditions for the intermediate hosts throughout the year. In the Palearctic and Nearctic regions, the intermediate hosts can complete the life cycle in the summer.

The pathological effects of $H$. acanthocephalicus have not yet been described. However, the histopathological changes caused by $H$. tricolor in the proventriculus of ducks were reported by Al-Labban et al. (2013), who observed that the cells were distributed irregularly, with infiltration of inflammatory cells. In addition to the inflammatory response in $P$. infuscatus of this study, parasites were found encapsulated and calcified. Similar inflammatory reactions were also reported by Clark (1978) in relation to Tetrameres tarapungae Clark 1978, in which the anterior end is also characterized by spines and the organ selected is the proventriculus.

Histrichosis is rare, but can cause large impacts on bird populations, as has been reported in Russia, Ukraine, and Georgia (KARMANOVA, 1986). Our new information on the histopathology of $H$. acanthocephalicus, in association with morphometric and prevalence data, among other information, will make it possible to recognize outbreaks in the Neotropical region. Finally, the parasitological indices of $H$. acanthocephalicus in $P$. infuscatus reported here were the first records for the Neotropical region.

\section{Acknowledgements}

We thank the Núcleo de Reabilitação da Fauna Silvestre/ Universidade Federal de Pelotas and the Instituto Chico Mendes de Conservação da Biodiversidade - Sistema de Autorização e Informação em Biodiversidade, for the license to catch the birds.

\section{References}

Al-Labban NQM, Dawood KA, Jassem GA. New parasites of local duck recorded in Iraq with histopathological study. Al-Qadisiya J Vet Med Sci 2013; 12(1): 152-161.

Amato JFR, Amato SB. Técnicas gerais para coleta e preparação de helmintos endoparasitos de aves. In: Von Matter S, Straube FC, Piacentini VQ, Accordi IA, Cândido JF Jr. Ornitologia e conservação: ciência aplicada, técnicas de pesquisa e levantamento. Rio de Janeiro: Technical Books; 2010. p. 367-394.
Anderson RC. Nematode parasites of vertebrates: their development and transmission. London: CABI International; 2000.

Belton W. Aves do Rio Grande do Sul: distribuição e biologia. São Leopoldo: Editora UNISINOS; 2003.

Bush AO, Lafferty KD, Lotz JM, Shostak AW. Parasitology meets ecology on its own terms: Margolis et al. revisited. J Parasitol 1997; 83(4): $575-$ 583. PMid:9267395. http://dx.doi.org/10.2307/3284227.

Canaris AG, Ortiz R, Canaris GJ. A predictable suite of helminth parasites in the long-billed dowitcher, Limnodromus scolopaceus, from the Chihuahua Desert in Texas and Mexico. J Parasitol 2010; 96(6): 1060-1065. PMid:21158610. http://dx.doi.org/10.1645/GE-2503.1.

Caputo LFG, Giritana LB, Manso PPA. Técnicas histológicas. In: Molinaro EM, Caputo LFG, Amendoeira MRR. Conceitos e métodos para a formação de profissionais em laboratórios de saúde. 2nd ed. Rio de Janeiro: Clark W; 2009. p. 89-188.

Clark WC. Tetrameres tarapungae n. sp. (Nematoda: Spirurida), a parasite of the red billed gull, Larus novaehollandiae scopulinus. NZ J Zool 1978; 5(1): 7-13. http://dx.doi.org/10.1080/03014223.1978.10423742.

Georgiev BB, Vaucher C. Chimaerula bonaisp. n. (Cestoda: Dilepididae) from the bare-faced ibis, Phimosus infuscatus (Lichtenstein) (Aves: Threskiornithidae) in Paraguay. Folia Parasitol (Praha) 2000; 47(4): 303-308. PMid:11151955. http://dx.doi.org/10.14411/fp.2000.052.

Hendricks LD, Harkema R, Miller GC. Hystrichis corvi sp. n. (Nematoda: Dioctophymatidae) from the Crow, and a Revised Key to the Species of Hystrichis. J Parasitol 1969; 55(6): 1201-1204. http://dx.doi. org/10.2307/3277258.

Karmanova EM. Dioctophymidea of animals and man and diseases caused by them: fundamentals of nematology. Washington: U.S. Department of Agriculture and the National Science Foundation; 1986.

Kavetska KM, Pilarczyk B, Królaczyk K. Stomach nematodes of wild ducks (Subfamily Anatinae) wintering in the North-Western Poland. Bull Vet 2012; 56(1): 27-31.

Kinsella JM, Hon L, Reed PB Jr. A comparison of the helminth parasites of the common gallinule (Gallinula chloropus cachinnans) and the purple gallinule (Porphyrula martinica) in Florida. Am Midl Nat 1973; 89(2): 467-473. http://dx.doi.org/10.2307/2424053.

Molin R. Il sottordine degli acrofalli ordinato scientificamente secondo $i$ risultamenti delle indagini anatomiche ed embriogeniche. Veneza: Presso la Segreteria dell'IR Institutó; 1861.

Sick H. Ornitologia Brasileira. Rio de Janeiro: Editora Nova Fronteira; 1997.

Travassos L, Freitas JFT. Relatório da sexta excursão do Instituto Oswaldo Cruz, realizada à zona da Estrada de Ferro Noroeste do Brasil, em novembro de 1941. Mem Inst Oswaldo Cruz 1942; 37(3): 259-286. http://dx.doi. org/10.1590/S0074-02761942000300004

Vashetko EV, Siddikov BH. The effect of the ecology of toads on the distribution of helminths. Turk J Zool 1999; 23: 107-110.

Vicente JJ, Rodrigues HO, Gomes DC, Pinto RM. Nematóides do Brasil Parte IV: Nematóides de aves. Rev Bras Zool 1995; 12(S1): 1-273. http:// dx.doi.org/10.1590/S0101-81751995000500001.

Youssefi M, Hosseini SH, Esfandiari B. First report of Hystrichis in Eurasian Otter (Lutra lutra) from Iran. Global Vet 2010; 4(4): 422-423. 